\title{
Exercise of Constitutional Human Rights on the Internet as a Factor of Sustainable Society Development
}

\author{
I.Yu. Ostapovich*, Yu.A. Gavrilova, M.N. Vilacheva, A.V. Savoskin \\ Ural State University of Economics, 8 Marta/Narodnoy Voli St. 62/45, 620144 Ekaterinburg, Russia
}

\begin{abstract}
There is a need to enshrine digital human rights in international acts and the Constitution to guarantee rights and freedoms for the purpose of sustainable development of society. It is due to the digitalization of public relations and the development of information and telecommunication means. It is worth noting that the fundamental international and domestic acts were adopted before the rights and freedoms became possible to be used on the Internet.
\end{abstract}

\section{Introduction}

The International Telecommunication Union (ITU) report "Measuring Digital Development: Facts and Figures for 2019" concludes that 4.1 billion people have access to the Internet. It is more than $50 \%$ of the world's population. Authorities and citizens of the Russian Federation actively use the Internet [1]. It has become an irreplaceable part of our life. Under such circumstances, it is undeniable that the Internet and its services are no longer just a tool for storing, transmitting and disseminating information. The internet has more than the communicative function. It has become an environment where people may exercise their constitutional rights.

In the authors' opinion the problem has not been sufficiently analyzed, since the Internet environment is constantly being updated, and information technologies are constantly being improved. So, the domain is difficult seeing that not everyone has access to it. The study is relevant as it relates to the sustainable development of society in the information environment.

\section{Materials and Methods}

The article uses the dialectical scientific, logical, historical, and systemic methods. The methods of comparative analysis and synthesis are of importance too. The functional method was applied to study the main directions of sustainable development of society. The study also uses the following general scientific methods: analysis, synthesis, and systemicstructural method. Special legal methods of cognition - comparative legal, formal legal method, formal logical method, technical legal method - are applied to analyze the

\footnotetext{
* Corresponding author: ostapovich7@mail.ru
} 
legislative regulation of Internet use in foreign countries. The main research material for the study is legislation and law enforcement practice in Russia and foreign countries in the field under study. The material is analyzed in two contexts. Firstly, there is a need to enshrine the digitalization of public relations in supranational legal acts. Secondly, the rules of conduct in the digital sphere should be prescribed by Constitution which gives rise to new state duty in the sphere of sustainable development of society. The study considers the concept of sustainable development of society. The article reflects general trends in the process of legal relationship and multidirectional features of the development of the phenomenon under comparative legal aspect.

\section{Results and Discussion}

The inalienable and imprescriptible human and civil rights written in Chapter 2 of the Constitution of the Russian Federation change in the virtual, electronic space and may be fully implemented only if citizens get unhindered access to the Internet.

The access may enable everyone to exercise many rights - the right to privacy, access to justice, freedom of speech, freedom of expression, information, protection of honor and dignity, personal and family secrets, petitions, management state affairs, education, reliable information about the state of the environment, etc.

However, it should be noted that the Internet environment is vulnerable and prone to cybercrimes. For example, there is possibility of unauthorized access to confidential and closed data, cyber terrorism, etc. Thus, the Plenum of the Supreme Court of the Russian Federation No. 48 "On judicial practice in cases of fraud, misappropriation and embezzlement" as of November 30, 2017 showed new methods of criminal theft. One of them is use of login identifications of an owner or other owners of a property, i.e. gaining access to such data secretly or by deception, using the victim's phone connected to the "mobile bank" service, authorization in the Internet payment system under the data of another person. In this regard, in addition to the properties of a positive nature, such as mass character, accessibility, universality, communication, there are negative ones [2]. It stops the sustainable development of the information society. Therefore, it seems necessary to analyze what rights we exercise through the Internet and how to protect them from negative manifestations, as well as to trace the issues people experience during their implementation and ways to solve them.

The access to the Internet was recognized as a basic human right in a UN resolution adopted on June 3, 2011. The global nature of informatization creates difficulties in defining jurisdiction over disputes. There are no general regulators of legal relationships on the Internet. There are now regulations establishing legal relationships in the field of intellectual and industrial property protection. There are no international acts that contribute to the development of a unified approach to regulation of digitalization.

Some countries restrict rights to the Internet. The Golden Shield Project in China blocks Google, YouTube, Instagram, Twitter; the Wikipedia is banned in Turkey; the Gwangmyeong-si replaces the public Internet in North Korea.

The Russian Federation recognizes the information society and creates a state program approved by the Government [3]. The new version of the state program of March 29, 2019 No. 356-24 defines the goals, objectives and measures for the implementation of the domestic and foreign policies in the sphere of application of information and communication technologies. The program is aimed at the development of an information society, the formation of a national digital economy, the implementation of strategic national priorities and serving national interests.

Activities of the national program "Digital Economy of the Russian Federation" are executed within the State Program. It is approved by the protocol of the Presidium of the 
Council under the President of the Russian Federation on Strategic Development and National Projects No. 16 as of December 24, 2018.

The actions may demonstrate that the state actively uses the electronic space, thus strengthens the legal regulation of the Internet and contributes to the creation of a sustainable society.

Besides, the Constitution of the Russian Federation prescribes the duty of the state to protect and defend the dignity of an individual as the unifying principle of all other human rights and freedoms and as a condition for their recognition and observance. But there are no norms dedicated to the right to the Internet. Some foreign countries reflect the guarantees at the constitutional level. The Part TWO of Article 5A of the Constitution of Greece says that everyone has the right to participate in the information society. The state is responsible for the assistance in access to information in electronic form, its production, exchange and dissemination. Part 6 of Article 35 of the Constitution of the Portuguese Republic guarantees the free access to public information networks. The French Constitutional Council declared the HADOPI Law adopted in 2009 unconstitutional. [4] The legislator indicated that a user who violated copyright on the Internet three times was deprived of access and was obliged to pay a fine.

Part 1 of Article 21 of the Constitution of the Russian Federation declares the state responsible for the protection of an individual dignity. Nothing can be the basis for belittling it. The right is inherent to everyone, regardless of citizenship (nationality). The essence of the right lies in the inviolability of the honor and dignity of each person and the possibility to demand from other individuals and legal entities to refrain from violating this right. The exercise of this right is to protect it.

The establishment of information rights at the constitutional level would guarantee the duty of the state to protect human rights in the event of their violation or unlawful restriction on the Internet. In the absence of such a right protected by law, citizens are not guaranteed the possibility of protection, which may lead to a violation of the right by law enforcement agencies and providers. The minimum data transfer rate is not fixed. The exercise of the right to access the Internet should be considered as belonging to everyone from birth, while its full implementation is possible upon reaching the age of 18, as V.N. Sereda noted [5]. A.A. Shcherbovich thinks that the main reason for the lack of the right to access the Internet in the constitutional and legal sphere is that the state has a corresponding obligation to provide infrastructure for access if this right is secured. It may aggravate the problem of the information explosion [6].

The Constitutional Court of the Russian Federation has repeatedly addressed the problem of protecting rights on the Internet. The rights and legitimate interests were asked to be subject to mandatory protection regardless of the information and communication technologies with the help of which the information was disseminated (Definition of the Constitutional Court of the Russian Federation of March 1, 2010 No. 323-O-O). The Constitutional Court of the Russian Federation indicated in 2013 that owners of a site or a person authorized by them are obliged to remove defamatory information in the presence of an appropriate court decision. The Court answered that other legal means may be used to suspend the dissemination of negative information pending a final resolution, i.e. measures to secure the claim. The court drew attention to the need to introduce additional legislative guarantees for the protection of honor, dignity and business reputation, considering a significant change in the methods of disseminating information on the Internet. Thus, "if information discrediting the honor, dignity or business reputation of a citizen is available on the Internet after its dissemination, the citizen has the right to demand the removal of the relevant information, as well as the refutation of the information in a way that ensures that the refutation is communicated to Internet users" (Resolution of the Constitutional Court of the Russian Federation as of July 9, 2013 No. 18-P). 
There are cases when websites are specially created to post false and often anonymous information or libel. Legal entities risk their business reputation due to such information, which leads to a decrease in customer confidence and a drop in sales.

However, false and negative information should be distinguished. The Arbitration Court of the Republic of Bashkortostan told that "the negative style of statement does not testify to its defamatory nature, since a negative judgment about an event is one of the manifestations of freedom of expression and thought, thus, it cannot be a basis for prosecution". Some scientists suggest prosecuting the users who committed an offense and the site owner. To our mind, the position is unreasonable, as the essence of responsibility is in its personal nature. Therefore, only those who committed the offense should take responsibility, unless owners contributed to him.

Such practice for the implementation of the right proves that the Internet is integrating more into life. So, the Supreme Court needs to issue a unified act that would regulate the most common controversial issues for the protection of the right on the Internet. The points are how to distinguish a fact from a subjective assessment, negative information from unreliable and the fact of confirming the authenticity of evidence.

A slander spreads instantly on the network. People asking the website's owners to delete such information are often denied such a request. The excuse is that the information will continue to spread, and the removal is meaningless. It is necessary to consolidate at the legislative level the obligations of all Internet companies to delete information at a written request, including the deletion of accounts on social networks.

The codified acts - the Criminal Code of the Russian Federation and the Code of Administrative Offenses of the Russian Federation - provide information on commission of an offense on the Internet. The offences include insults, the administrative responsibility for which and the criminal liability are prescribed by Article 5.61 and Article 282 of the Criminal Code of the Russian Federation resp. Protection of honor and dignity on the Internet is an open and controversial question, as sometimes it is impossible to find the violators of the right. They are often strangers or even fake. The competent authorities have the necessary methods and means to solve the problem. The issue is dealt with by the department that includes the Ministry of Internal Affairs of the Russian Federation. A victim can count on the protection of their rights if such a situation arises. However, a violator is easy to recognize when the domain name is used, since there is an opportunity to enter the Internet at a public place that has a distribution point without authorization. There is an administrative liability for non-compliance with the law on "On information, information technology and the protection of information «written in Article 13.30 of the Code of Administrative Offenses of the Russian Federation.

There exists a problem to identify a person who has committed offenses in a foreign country. The German ruling coalition decided to abolish the responsibility for the actions of users on the Web on the owners. The head of the Federal Association of Information, Telecommunication and Computer Technologies Bitcom Bernhard Rohleder support it. Public institutions will not be responsible for other people's illegal actions, and visitors will no longer have to go through a complicated registration procedure to connect to the Network [7]. In our opinion, it is a huge disadvantage, since there would be no mechanisms to protect human rights. User identification should be obligatory to find the owner of the device from which an offence was committed.

Elimination of the restrictions as in Germany would be a pretext for a sense of impunity. The problem may be solved only by complete unification of national and regional legislation on the Internet issues. It necessary to consolidate the regulation at the international level and to get the maximum of member-states involved.

Not only personal constitutional rights may be realized on the Internet. The right to labor is constitutional too. A person has the right to labor, to a free choice of work, to 
protection from unemployment, to comfortable working conditions, to a decent remuneration for labor.

The development of the Internet environment helps to exercise the right to labor by working remotely. The Labor Code was supplemented by Chapter 49.1 "Features of the regulation of work of homeworkers". It states that a remote employee and an employer can contact about the issues related to the performance of the labor function on public information and telecommunication networks, i.e. the Internet. The employees have flexible schedule, work without leaving home and organize the workplace on their understanding of comfort. The employer reduces the cost of maintaining the workplace. A special assessment of working conditions is not obligatory. An employment contract is executed with an electronic signature. Thus, the costs of the employer and the employee are significantly reduced. Teleworking provides equal conditions for people with disabilities.

In 2019 the All-Russian Popular Front appealed to the Ministry of Labor and Social Protection with a demand to amend the Labor Code and allow staff members to work remotely from time to time, to introduce the concept of "temporary remote work" into Chapter 16 of the Labor Code of the Russian Federation ("Working hours"). If the proposed amendments are adopted, the employee will have the right to spend part of the time outside his workplace. Since such a mode of work is not provided for by the Labor Code, this often leads to attempts to fire an employee or formalize his absenteeism [8]. This is another gap in the legislation, which leads to a worsening of the employee's position.

The right to protection from unemployment is directly related to the right to labor. The coronavirus epidemic and the measures taken by the state to protect citizens change the legislation to implement state guarantees of the constitutional rights of citizens of the Russian Federation to work and social protection from unemployment. So, the employment services of the population work remotely. Thus, the Resolution of the Government of the Russian Federation as of April 8, 2020 approved temporary rules for the registration of unemployed, citizens searching for suitable work. It also confirms the implementation of social payments to citizens recognized as unemployed.

Part 1 of Article 3 of the Law of the Russian Federation "Concerning Employment in the Russian Federation" defines unemployed citizens as able-bodied citizens without work or earnings, searching for work and ready to start it, registered in the employment service bodies to find a suitable one. Clause 2 of the temporary rules states that registered citizens are those who submitted an application in electronic form to the personal account of the information and analytical system All-Russian database of vacancies "Work in Russia" or to the personal account of the federal state information system "Unified Public Services Portal (UPSP)". The access to the portals is affected if there is access to the Internet. So, the problem is how to exercise the right to labor and protection from unemployment for the citizens who do not have such access. There is a gap between Moscow, St. Petersburg and other regions, and a large difference of price and access speed.

Part 1 of Article 43 of the Constitution guarantees the right to education. "The state of the Russian education system and the need for its modernization" reads that attention should be paid to the need to change teaching methods, to raise the level of those that form practical skills of information analysis, self-study, stimulate independent work of students and form experience of self-organization. The state of education in Russia and trends of the development of society require a solution to the problem of the advanced development of the education system based on information technologies through creation of a unified educational information environment in the country" (Concept for the modernization of Russian education, approved by the government of the Russian Federation, clause 1.3) [9]. New information technologies in educational processes lead to a new educational system that provides educational services to the most of citizens through the educational resources 
of the Internet. There is a complete informatization of education. The main task of it is to form qualitatively new results, which would become habitual to us.

Internet technologies provide students with unlimited learning opportunities. Teaching staff adopts a differentiated learning approach. The educational resources used improve the learning process, create new and high levels of learning. Students implement new opportunities in the learning process, while teachers improve it.

There is a guarantee to get higher education on a competitive basis. So, universities are introducing distance learning for students and teachers to interact on the Internet. Even such an education demands to take tests, term papers, and exams. The teacher places lectures and gives seminars. A right approach to distance learning makes it as good as the full-time one. Its cost is significantly lower, and the student may get knowledge even at a great distance. The type of education is useful for advanced vocational training and second higher education with time shortage.

The coronavirus pandemic made educational institutions shift to distance learning. So, the right to study may be exercised only through the Internet. The use of Internet resources in education has limitations, i.e. absence of the global network in remote communities. The results of a survey conducted by experts from the All-Russian Popular Front show that " $80 \%$ of the respondents encountered problems when shifting to distance learning." The most common problems are the lack of computers and mobile devices, technical problems in schools and a lack of Internet experience.

In practice, online learning provides a disproportionate benefit to students with a better position. It is also a disadvantage. The state needs to introduce free Internet for such categories and take measures to quickly introduce broadband Internet to remote communities. Some states have already begun to take such actions, as the UK broadband providers give citizens free unlimited Internet [9].

The Organization for Economic Co-operation and Development (OECD) settled the main tasks for the implementation of digital learning. Thus, one of them is to provide the students with portable computers or other resources for learning, since students have more access to smartphones [10].

In Cyprus banks and philanthropists provide needy children with electronic devices (6 thousand electronic tablets have already been received), and telecommunications operators provide free Internet access to provide distance learning. The Ministry of Education and Science has collected data from all schools in Cyprus in order to identify student needs. In Hong Kong Microsoft Provides Free Use of Office 365 Education for 50,000 Teachers and 800,000 Students.

There are only sanctions in Russia. For example, the authorities of the Perm Krai think to have a file on children from the village of Novopetrovka, as the latter climbed the television tower to send their homework [11]. Children from Bashkiria region go to the Chelyabinsk region to download their homework, since there is no stable and fast signal in their settlement [12].

Coronavirus showed that it is necessary to prescribe the right to the Internet in the Constitution, which will give rise to the state's obligation to provide everyone with access to the Internet, even if it is paid. The exercise of rights should be guaranteed not only in life, but also in the virtual world, since the exercise of these rights by those who have such access and the impossibility of exercising by others leads to the derogation of rights, which is prohibited in our Constitution (part 2 of article 55).

\section{Conclusion}

There was found a technological lag in certain indicators from foreign countries in the sphere of information production and a "digital divide". Thus, an active government policy 
is needed to eliminate the problems by reducing Internet prices for certain categories of citizens (students, pensioners).

Legal regulation in the sphere should be developed to standardize the actions clearly, to eliminate uncertainties, and to protect rights. The content of the right needs to be defined too. Legal regulation at the international and national levels for the "right to access the Internet" would make the state responsible for implementation of effective mechanisms to protect rights on the Internet. Recognition of the right as fundamental would be a motivation for states to fulfill effectively positive obligations. It would guide the development of state ICT policies to the interests of individuals to ensure free and nondiscriminatory access to the Internet as a universal service. It would also limit the possibility of states to deny freedom of access to the Internet as one of the key freedoms of the modern information society. The fact is confirmed by the European Court of Human Rights [13]. The foregoing would allow minimizing arbitrariness in limiting human rights and freedoms by establishing the framework of permitted.

Thus, sustainable development of society may be achieved if a balance between the effective implementation of constitutional rights and freedoms in the global information and telecommunication Internet environment is maintained and the protection of constitutional values and the human rights and freedoms from the risks generated by the Internet environment is guaranteed. A comprehensive approach should be developed to restrict rights on the Internet reasonably. It would combine legislative regulation on the mechanism for the implementation of rights in a virtual environment, the establishment of additional guarantees for the exercise and protection of the rights, and the development and consolidation of the legal positions of judicial practice. A codified act that normatively fixes the legal basis for the Internet use is necessary to be adopted. Such a document would become the basic one for defining the rights and obligations of ordinary users of the information and communication space and governmental units.

Practice showed that targeted regulation by certain legislative acts in the Russian Federation is not enough to ensure full protection of citizens' interests. The consolidation of such categories as "the right to the Internet", "the right to access the Internet" in the documents would simplify the procedure of bans introduction. The regulation of legal relationships on the Internet by various regulatory legal acts prevents a clear perception of the introduction of the measures. It only strengthens the public's reaction to the imposed prohibitions. The aspects of the exercise of rights by citizens in the Internet sphere are considered, the state would be able to ensure reliable protection of public interests from abuse on the Internet.

In the modern period, there is a need to determine all the elements of the right to access the Internet: the rights exercised on the Internet, to compare them with the rights enshrined in international normative legal acts, in the Constitution of Russia or other legal documents. The constitutional foundations that determine the implementation of the rights and freedoms of citizens in the field of access to information, its receipt and distribution, as well as the right to access the Internet, are the guarantors of sustainable development of society.

\section{References}

1. The number of Internet users in the world has grown to 4.1 billion people, http://fapmc.ru

2. P.U. Kuznetsov, Information technology in legal practice (2018)

3. Resolution of the Government of the Russian Federation (2014)

4. In France, the inoperative pirate law HADOPI has been canceled, http://www.copyright.ru 
5. V. N. Sereda, M. Yu. Sereda, Protection of human and civil rights and freedoms on the Internet (2013)

6. A. A. Shcherbovich, Constitutional Right to Access the Internet: World Experience and Conclusions for Russia (2015)

7. Unlike Russia, Germany gives the green light for WiFi in public places, http://www.profi-forex.org

8. The concept of "temporary remote work" will be introduced into the Labor Code, https://www.eg-online.ru

9. T.A. Makhmutov, How the coronavirus is changing education: global problems and the experience of other countries, https://ach.gov.ru

10. Education responses to covid-19: Embracing digital learning and online collaboration, https://read.oecd-ilibrary.org

11. The Perm authorities will register children who sent tasks from the TV tower, https://ria.ru

12. Bashkir schoolchildren go to the Chelyabinsk region to download their homework, https://www.1obl.ru

13. K. U. v. Finland. judgment of 2 December 2008, application no.2872 / 02, http://www.echr.coe.int

14. M. D. Griffiths, Psychology and the Internet (1998)

15. S. N. Paul, Lee Louis Leung, The influences of information literacy, internet addiction and parenting styles on internet risks (2012)

16. M.D. Griffiths, Gambling on the Internet: A brief note. Journal of Gambling Studies (1996) 